\title{
PENGARUH KEBIASAAN BELAJAR SISWA DAN KECERDASAN EMOSI SERTA PERHATIAN ORANG TUA TERHADAP PENGUASAAN KONSEP MATEMATIKA
}

\author{
Gerry Sastro \\ Program Studi Matematika, FMIPA - UNPAM \\ dosen00544@unpam.ac.id
}

\begin{abstract}
The background of the research is the education of the nation's children who tend to emphasize the problem of intellectual intelligence without seeing the factors of learning habits, emotional intelligence and the role of parents who are important to support the success of students in achievement. The purpose of research to determine the influence of learning habits and emotional intelligence and parents' attention together to mastery of mathematical concepts. The research used survey method, sampling technique using random sampling which amounted to 456 students from three private Junior High School in Pamulang Sub-district, Tangerang Selatan City. Data analysis using Multiple Regression. The results showed that mastery of mathematical concepts influenced jointly by study habits, emotional intelligence, and attention of parents with regression equation $\hat{Y}=49,376+0,324 X_{1}+0,311 X_{2}+0,448 X_{3}$. Partially also mastery of mathematical concepts influenced by learning habits. Mastery of mathematical concepts influenced by emotional intelligence and mastery of mathematical concepts influenced by the attention of parents. The implications of the research are the attention of parents giving a dominant contribution to the mastery of mathematical concepts rather than learning habits and emotional intelligence. It is advisable for parents to give much attention to their children to improve the learning outcomes of mathematics.
\end{abstract}

Keywords: study habits, emotional intelligence, parental attention, mastery of mathematical concepts.

\begin{abstract}
ABSTRAK
Latar belakang penelitian adalah pendidikan anak bangsa yang cenderung menekankan masalah kecerdasan intelektual tanpa melihat faktor kebiasaan belajar, kecerdasan emosi dan peran orang tua yang sebenarnya penting menunjang keberhasilan siswa dalam meraih prestasi. Tujuan penelitian untuk mengetahui pengaruh kebiasaan belajar dan kecerdasan emosi serta perhatian orang tua secara bersama-sama terhadap penguasaan konsep matematika. Penelitian menggunakan metode survey, teknik pengambilan sampel menggunakan random sampling yang berjumlah 456 siswa dari tiga SMP Swasta di Kecamatan Pamulang Kota Tangerang Selatan. Analisis data menggunakan Regresi Berganda. Hasil penelitian menunjukkan bahwa penguasaan konsep matematika dipengaruhi secara bersama-sama oleh kebiasaan belajar, kecerdasan emosi, dan perhatian orang tua dengan persamaan regresi $\hat{Y}=49,376+0,324 X_{1}+0,311$ $\mathrm{X}_{2}+0,448 \mathrm{X}_{3}$. Secara parsial pula penguasaan konsep matematika dipengaruhi oleh kebiasaan belajar. Penguasaan konsep matematika dipengaruhi oleh kecerdasan emosi dan penguasaan konsep matematika dipengaruhi oleh perhatian orang tua. Implikasi dari
\end{abstract}


penelitian adalah perhatian orang tua memberikan kontribusi dominan pada penguasaan konsep matematika dari pada kebiasaan belajar dan kecerdasan emosi. Maka disarankan orang tua untuk memberikan banyak perhatian kepada anaknya untuk meningkatkan hasil belajar matematika.

\section{Kata kunci: kebiasaan belajar, kecerdasan emosi, perhatian orang tua, penguasaan konsep matematika.}

\section{PENDAHULUAN}

\subsection{Latar Belakang Masalah}

Pendidikan nasional, sebagai salah satu sektor pembangunan nasional dalam upaya mencerdaskan kehidupan bangsa, mempunyai visi terwujudnya sistem pendidikan sebagai pranata sosial yang kuat dan berwibawa untuk memberdayakan semua warga negara Indonesia berkembang menjadi manusia yang berkualitas sehingga mampu dan proaktif menjawab tantangan zaman yang selalu berubah. Makna manusia yang berkualitas, menurut Undang-Undang Nomor 20 Tahun 2003 tentang Sistem Pendidikan Nasional, yaitu manusia terdidik yang beriman dan bertakwa kepada Tuhan Yang Maha Esa, berakhlak mulia, sehat, berilmu, cakap, kreatif, mandiri, dan menjadi warga negara yang demokratis dan bertanggung jawab.

Pendidikan pada dasarnya merupakan upaya yang paling utama untuk mencerdaskan kehidupan bangsa. Melalui pendidikan yang bermutu, dapat membangun keunggulan dalam menghadapi persaingan global yang semakin cepat. Pendidikan merupakan salah satu faktor yang sangat penting artinya dalam kehidupan manusia dan tidak dapat dipisahkan darinya dimanapun berada. Karena sifatnya yang mutlak itulah dalam setiap aspek kehidupan manusia baik secara pribadi, kelompok, keluarga, maupun dalam berbangsa dan bernegara, pendidikan wajib dilaksanakan.

Namun kenyataannya kondisi pendidikan di Indonesia dewasa ini masih jauh dari harapan, hal ini disebabkan oleh mutu kualitas dan pengelolaan pendidikan masih rendah. Oleh sebab itu, mulai sejak dini kita harus meningkatkan mutu sumber daya manusia dan menciptakan generasi muda yang bermoral baik serta berkualitas. Untuk menjadikan pendidikan berkualitas sangat ditentukan oleh kualitas pemprosesan dan pengelolaannya dengan asumsi bahwa untuk meningkatkan mutu pendidikan maka proses belajar mengajar harus dibenahi dengan baik. 
Dunia pendidikan dewasa ini mendapat tantangan untuk menghasilkan sumber daya manusia yang berkualitas, yaitu sumber daya manusia yang mampu hidup di alam Globalisasi. Pendidikan sebagai pencetak sumber daya insani sepatutnyalah mendapat perhatian secara terus menerus untuk meningkatan mutunya. Peningkatan mutu pendidikan berarti pula peningkatan kualitas sumber daya manusia.

Matematika juga dikatakan sebagai sumber dari ilmu-ilmu lain. Matematika bila dipelajari dengan hati yang senang dapat menciptakan susasana permainan yang menyenangkan, secara tidak langsung dapat meningkatkan kemauan untuk belajar. Kemauan belajar peserta didik yang konsisten secara terus menerus akan menjadikan belajar menjadi bagian dari kebiasaan yang konsisten.

Mata pelajaran matematika perlu diberikan kepada semua peserta didik mulai dari sekolah dasar untuk membekali peserta didik dengan kemampuan berpikir logis, analitis, sistematis, kritis, dan kreatif, dan kemampuan bekerjasama (Permendiknas, Nomor 22, 2006: 345). Kemampuan itu diperlukan agar peserta didik dapat memiliki kemampuan memperoleh, mengelola, dan memanfaatkan informasi untuk bertahan hidup pada keadaan yang selalu berubah, tidak pasti, dan kompetitif.

Matematika pada hakekatnya merupakan sistem aksiomatis deduktif formal. Sebagai suatu sistem aksiomatis, matematika memuat komponen-komponen dan aturan komposisi atau pengerjaan yang dapat menjalin hubungan secara fungsional antar komponen. Sehingga, matematika dikenal sebagai pengetahuan yang terstruktur, sistematis, tersusun secara hierarkis, dan terjalin hubungan fungsional yang erat antar komponen. Komponen-komponen tersebut adalah fakta, konsep, prinsip dan prosedur. Ini berarti fakta, konsep, prinsip dan prosedur tersebut tersusun secara hierarkis.

Menurut Sumarmo (2013:4) menyatakan bahwa secara garis besar kemampuan dasar matematika dapat diklasifikasikan dalam lima standar, yaitu (1) mengenal, memahami, dan menerapkan konsep, prosedur, prinsip dan idea matematika, (2) menyelesaikan masalah matematika (mathematical problem solving), (3) bernalar matematika (mathematical reasoning), (4) melakukan koneksi matematika (mathematical connection), dan (5) komunikasi matematika (mathematical communication).

Matematika merupakan kreasi pemikiran manusia yang pada intinya berkait dengan ide-ide, proses-proses dan penalaran. Dengan demikian, guru matematika seharusnya mengembangkan kemampuan penalaran peserta didik di dalam proses 
pembelajaran matematika, tetapi kenyataan di lapangan berdasarkan hasil penelitian kemampuan penalaran peserta didik masih kurang, seperti yang dikemukakan oleh laporan penelitian menemukan kualitas kemampuan penalaran dan penguasaan matematika peserta didik belum memuaskan, yaitu masing-masing sekitar $49 \%$ dan 50 $\%$ dari skor ideal.

Fakta di lapangan guru matematika sekolah kebanyakan mengajar dengan cara tradisional dengan pola: informasi-contoh soal-latihan sesuai contoh. Paradigma pembelajaran matematika di Indonesia selama bertahun-tahun adalah paradigma mengajar dan banyak dipengaruhi oleh psikologi tingkah laku, bukan paradigma belajar. Menurut Ratumanan yang dikutip oleh Rochmadi (2008 : 2) bahwa :

Pembelajaran matematika di Indonesia beracuan behaviorisme dengan penekanan pada transfer pengetahuan dan hukum latihan. Guru mendominasi kelas dan menjadi sumber utama pengetahuan, kurang memperhatikan aktivitas aktif peserta didik, interaksi peserta didik, negosiasi makna, dan konstruksi pengetahuan.

Matematika memiliki peran yang penting dalam pendidikan karena merupakan pengetahuan dasar yang diperlukan oleh peserta didik untuk menunjang keberhasilan belajarnya dalam menempuh pendidikan yang lebih tinggi. Selain itu keberadaan matematika juga selalu ada disektor kehidupan manusia karena disadari atau tidak pada kenyataannya dalam kegiatan sehari-hari tidak terlepas dari peran matematika. Banyak peserta didik yang berasumsi bahwa pelajaran matematika yang diberikan di sekolah itu sulit dan membosankan sehingga banyak peserta didik yang kurang tertarik dengan pelajaran matematika, itulah pendapat yang penulis dapatkan dari peserta didik SMP Swasta di Kecamatan Pamulang Kota Tangerang Selatan).

Penguasaan konsep Matematik siswa berhubungan dengan seberapa banyak dan seberapa kaya hubungan-hubungan yang mereka buat. Contohnya bila siswa diminta untuk membuat sebuah grafik dengan cara $=X^{2}-X-12$, siswa mungkin ada yang membuat grafik dengan cara menentukan dimana fungsi memotong sumbu $\mathrm{x}$ kemudian mencari dimana nilai minimum fungsi tersebut, mungkin juga ada siswa yang membentuk sketsa grafik dengan cara membentuk tabel fungsi untuk beberapa nilai sebagian data yang digunakan dalam membuat sketsa grafik itu.

Matematika secara umum sangat sulit dipahami oleh siswa, karena matematika memiliki obyek yang sifatnya abstrak dan membutuhkan penalaran yang cukup tinggi 
untuk memahami setiap konsep-konsep matematika yang sifatnya hirarkis, sehingga perlu menerapkan model-model pengajaran yang lebih baik dan tepat membantu penguasaan siswa sedini mungkin di tingkat sekolah terhadap matematika. Tetapi perlu kita garis bawahi pula sebuah pengajaran yang baik tidak cukup untuk mendapatkan hasil belajar siswa yang optimal, karena yang menjadi salah satu masalah yang dihadapi guru untuk menyelenggarakan pengajaran matematika adalah bagaimana menumbuhkan dan merangsang kemampuan penalaran (logika) serta penguasaan konsep dengan benar oleh siswa.

Penguasaan konsep Matematika membantu siswa untuk mengingat, hal tersebut dikarenakan idea-idea Matematika yang dipelajari melalui penguasaan adalah saling terhubung. Mereka dapat lebih mudah untuk mengingat dan menggunakan, serta dapat menyusun kembali pada saat mereka lupa, siswa yang mengingat kembali apa yang mereka pahami dan mencoba untuk mempresentasikan kedalam sendiri.

Menurut Abdul Rahman (2008:269) Kecerdasan sangat mempengaruhi perkembangan individu seseorang. Dalam kesehariannya terlihat perbedaan kemampuan dalam pelaksanaan kegiatan sehari-hari dan dalam menyelesaikan masalah. Bagi anakanak yang memiliki tingkat kecerdasan diatas rata-rata maka ia dapat melaksanakan dan menyelesaikan tugas dengan cepat dan berhasil. Akan tetapi sebaliknya, jika seorang anak memiliki tingkat kecerdasan dibawah rata-rata, ia akan sulit untuk melaksanakan tugasnya.

Pada dasarnya hasil kemampuan penguasaan konsep matematika dipengaruhi oleh beberapa faktor diantaranya faktor intelegensia atau kecerdasaan. Faktor intelegensi atau kecerdasan merupakan salah satu faktor terpenting pada peserta didik. Karena dengan tingkat kecerdasan yang tinggi seorang siswa dapat menyelesaikan soal-soal secara cepat dan tepat. Tetapi kecerdasan bukan satu satunya tolak ukur seorang siswa memperoleh prestasi yang tinggi, karena bisa saja seorang siswa dengan tingkat kecerdasannya biasa saja dapat mempunyai prestasi yang tinggi dibandingkan dengan siswa yang mempunyai tingkat kecerdasan yang tinggi. Itu semua bisa terjadi karena faktor-faktor lain yang mempengaruhinya.

Kebiasaan belajar siswa merupakan salah satu faktor pendukung keberhasilan siswa dalam menempuh jenjang belajar yang sedang ditempuh siswa tersebut. Bila kebiasaan belajar baik, maka prestasi yang diharapkan tentunya juga baik. Kebiasan ini dapat timbul 
dari sikap mental yang tepat terhadap hal-hal yang berhubungan dengan aktifitas belajar. Disiplin pribadi diperlukan pula untuk mengembangkan kebiasaan-kebiasaan baik itu sehingga kelak dapat terlaksana tanpa banyak kesulitan.

Selama bertahun-tahun Kecerdasan Intelegensi (IQ) telah diyakini menjadi ukuran standar kecerdasan, namun sejalan dengan tantangan dan suasana kehidupan modern yang serba kompleks, ukuran standar IQ ini memicu perdebatan sengit dan sekaligus menggairahkan di kalangan akademisi, pendidik, praktisi bisnis dan bahkan publik awam, terutama apabila dihubungkan dengan tingkat kesuksesan atau prestasi hidup seseorang. Steiner (1997) menjelaskan pengertian kecerdasan emosional adalah suatu kemampuan yang dapat mengerti emosi diri sendiri dan orang lain, serta mengetahui bagaimana emosi diri sendiri terekspresikan untuk meningkatkan maksimal etis sebagai kekuatan pribadi. Kecerdasan Emosional (Emotional Intelligence) Daniel Goleman berpendapat bahwa Kecerdasan dapat terdiri dari kombinasi 5 komponen, yaitu kesadaran diri, manajemen emosi, motivasi, empati, dan mengatur hubungan atau relasi. (Haryanto,S.Pd/Jurnal psikologi/kecerdasan emosional, diposkan 05-09- 2010, diunduh 01-06-2015).

Seiring dengan perkembangan ilmu pengetahuan dan teknologi, kini kecerdasan emosi manusia sangat berperan dalam segala aspek kehidupan manusia. Kecerdasan emosi adalah kemampuan mengenali perasaan kita sendiri dan perasaan peserta didik lain, kemampuan memotivasi diri sendiri, dan kemampuan mengelola emosi dengan baik pada diri sendiri dan dalam hubungan dengan peserta didik lain. Peserta didik yang mempunyai kecerdasan emosi yang tinggi merupakan peserta didik yang dapat meraih kesuksesan pekerjaan, hubungan jangka panjang dengan peserta didik lain serta memiliki kerja yang seimbang dan kehidupan rumah tangga.

Perhatian orang tua sangat diperlukan untuk menanamkan disiplin belajar pada anak-anaknya, misalnya mengatur waktu bermain, mengatur dalam menonton televisi, membaca buku, majalah, dan koran perlu adanya pengawasan atau perhatian dari orang tua, meskipun kita juga perlu memberi kebebasan bagi anak. Kebebasan yang dimaksud adalah kebebasan yang tetap terkendali atau terpantau oleh orang tua. Banyak kita jumpai sebagai orang tua tidak peduli dengan hal-hal yang demikian, mereka masa bodoh dengan apa yang dilakukan oleh anaknya. Mereka selalu beralasan yang lelah seharian, kerja yang sibuk, dan menyibukkan diri dengan berbagai acara dan berbagai alasan yang mengakibatkan tidak sempat memperhatikan belajar anaknya. 
Berdasarkan kasus-kasus di atas, jika seorang anak ingin sukses dalam belajarnya maka harus dipahami bentuk-bentuk perhatian orang tua yang dapat dilakukan pada anaknya. Bentuk perhatian orang tua terhadap belajar anak dapat berupa pemberian bimbingan dan nasihat, pengawasan terhadap belajar anak, pemberian motivasi dan penghargaan serta pemenuhan kebutuhan belajar anak.

Dalam upaya orang tua memberikan bimbingan kepada anak yang sedang belajar dapat dilakukan dengan menciptakan suasana diskusi di rumah. Banyak keuntungan yang dapat diambil dari terciptanya situasi diskusi di rumah antara lain; memperluas wawasan anak, melatih menyampaikan gagasan dengan baik, terciptanya saling menghayati antara orang tua dan anak, orang tua lebih memahami sikap pandang anak terhadap berbagai persoalan hidup, cita-cita masa depan, kemauan anak, yang pada gilirannya akan berdampak sangat efektif bagi daya dukung terhadap kesuksesan belajar anak.

Dari uraian tersebut, penulis tertarik untuk melakukan penelitian dengan judul "Pengaruh Kebiasaan Belajar Siswa Dan Kecerdasan Emosi Serta Perhatian Orang Tua Terhadap Penguasaan Konsep Matematika“. Dengan memahami keterkaitan tersebut diatas, diduga bahwa terdapat pengaruh kebiasaan belajar siswa dan kecerdasan emosi serta perhatian orang tua terhadap penguasaan konsep matematika. Siswa yang mempunyai kebiasaan belajar baik dan kecerdasan emosi tinggi serta adanyan perhatian orang tua dapat penguasaan konsep matematika dengan baik.

\subsection{Rumusan Masalah}

1) Berdasarkan latar belakang masalah yang ada di atas maka dapat di identifikasi masalah sebagai berikut:

2) Faktor apakah yang dapat meningkatkan kemampuan penguasaan konsep matematika siswa?

3) Faktor apakah yang dapat menimbulkan kegagalan didalam pembelajaran?

4) Faktor apa yang menyebabkan siswa merasa takut terhadap pelajaran matematika?

5) Bagaimana cara untuk menghilangkan rasa takut dan tidak senang terhadap pembelajaran matematika?

6) Bagaimana cara untuk meningkatkan kecerdasan siswa?

7) Bagaimana cara meningkatkan penguasaan konsep yang baik bagi siswa dalam mempelajari Matematika?

8) Faktor apa sajakah yang yang dapat meningkatkan kecerdasan emosi siswa? 
9) Apakah terdapat pengaruh langsung kecerdasan emosi siswa terhadap kemampuan penguasaan konsep matematika siswa?

10) Apakah terdapat pengaruh langsung kebiasaan belajar siswa terhadap penguasaan konsep matematika siswa?

11) Apakah terdapat pengaruh langsung kebiasaan belajar siswa dan kecerdasan emosi siswa terhadap kemampuan penguasaan konsep matematika?

12) Apakah terdapat pengaruh tidak langsung kebiasaan belajar siswa dan kecerdasan emosi siswa terhadap kemampuan penguasaan konsep matematika?

13) Apakah terhadap pengaruh langsung perhatian orang tua terhadap penguasaan konsep matematika?

14) Apakah terdapat pengaruh kebiasaan belajar siswa dan perhatian orang tua terhadap kemampuan penguasaan konsep matematika?

15) Apakah terdapat pengaruh tidak langsung kebiasaan belajar siswa dan perhatian orang tua terhadap kemampuan penguasaan konsep matematika?

16) Apakah terdapat pengaruh kecerdasan emosi siswa dan perhatian orang tua terhadap kemampuan penguasaan konsep matematika?

\subsection{Tujuan Penelitian}

Tujuan yang ingin dicapai dalam penelitian ini adalah untuk menganalisis secara empiris adanya:

1) Pengaruh kebiasaan belajar siswa, kecerdasan emosi, dan perhatian orang tua secara bersama-sama terhadap kemampuan penguasaan konsep matematika siswa.

2) Pengaruh kebiasaan belajar siswa terhadap kemampuan penguasaan konsep matematika siswa.

3) Pengaruh kecerdasan emosi siswa terhadap kemampuan penguasaan konsep matematika siswa.

4) Pengaruh perhatian orang tua terhadap kemampuan penguasaan konsep matematika siswa.

\subsection{Manfaat Penelitian}

Manfaat teoritis dari penelitian yang dibahas antara lain untuk mengungkap pengaruh kebiasaan belajar siswa, kecerdasan emosi dan perhatian orang tua secara bersama-sama terhadap penguasaan konsep matematika siswa.

Kegunaan praktis dari penelitian yang dibahas antara lain: 
1. Bagi siswa adalah jangan mudah menyerah pada prediksi tes kemampuan intelegensi yang belum tentu kebenarannya seratus persen yang akan menjamin masa depan seseorang. Namun ada faktor lain yang lebih menunjang keberhasilan seseorang yang diharapkan sebagai bahan pertimbangan untuk memperoleh prestasi yang lebih maksimal.

2. Bagi guru adalah sebagai bahan pertimbangan bahwa kebiasaan belajar, kecerdasan emosi dan perhatian orang tua dapat mempengaruhi penguasaan konsep siswa yang maksimal.

3. Bagi sekolah adalah penelitian ini dapat dijadikan masukan dan cermin untuk menilai siswa jangan dari segi kemampuan intelegensi saja namun dapat menerima kelebihan siswa dari faktor lain.

\section{METODOLOGI PENELITIAN}

Metode penelitian adalah cara ilmiah untuk mendapatkan data yang valid dengan tujuan dapat ditemukan, dikembangkan, dan dibuktikan, suatu pengetahuan tertentu sehingga pada gilirannya dapat digunakan untuk memahami, memecahkan dan mengantisipasi masalah.

Metode yang digunakan oleh peneliti dalam penelitian ini adalah metode survey dengan melalui pengumpulan data langsung dari responden, untuk memperoleh data kebiasaan belajar, kecerdasan emosional, dan perhatian orang tua peneliti mengumpulkan data dengan menggunakan kuesioner, untuk memperoleh data penguasaan konsep matematika peneliti menggunakan metode survey terhadap hasil belajar matematika siswa pada tahun pelajaran 2014-2015.

Untuk mengetahui hubungan antar variabel dalam penelitian ini, peneliti menyusun hubungan antar variabeldalam bentuk diagram jalur berikut ini:

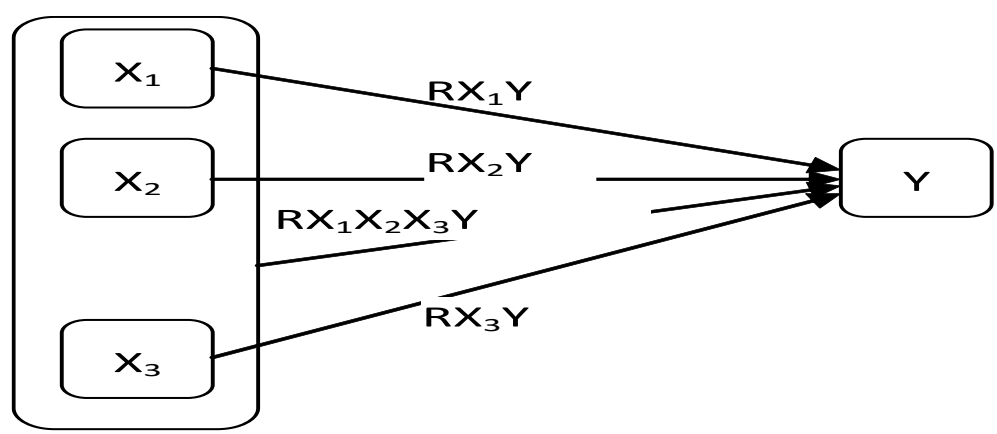

Gambar 2.1 Desain Penelitian 
Dari diagram jalur di atas dapat dijelaskan bahwa X1 merupakan variabel independen (eksogen) dari X2 dan X3. X1 mempunyai jalur hubungan langsung dengan $\mathrm{X} 3$, tetapi juga mempunyai jalur hubungan tidak langsung dengan $\mathrm{X} 3$ karena harus melalui X2. Dalam hal ini variabel X2 dan X3 merupakan variabel endogen. Adapun variabel dalam penelitian ini terdiri dari: Variabel bebas (X1) kebiasaan belajar siswa, variabel intervening (X2) kecerdasan emosional, dan variabel bebas (X3) perhatian orang tua serta variabel terikat $(\mathrm{Y})$ penguasaan konsep matematika.

\subsection{Populasi dan Sampel}

\subsubsection{Populasi Target}

Menurut Supardi (2012: 25) menyatakan bahwa "populasi adalah subyek yang berada pada satu wilayah dan memenuhi syarat-syarat tertentu berkaitan dengan masalah atau objek penelitian".

Populasi pada penelitian ini adalah seluruh siswa kelas VIII SMP Swasta Kota Tangerang Selatan yang terdaftar pada tahun pelajaran 2014/2015 dengan jumlah sampel sebanyak 456 siswa.

\subsubsection{Sampel}

Untuk menentukan Ukuran sampel, peneliti mengacu kepada ketentuan yang dijelaskan oleh Suharsimi Arikunto, (2006:134) yaitu apabila subjeknya kurang dari 100 lebih baik diambil semua sehingga penelitiannya merupakan penelitian populasi. Tetapi, jika jumlah subjeknya besar, dapat diambil antara 10\% - 15\% atau 20\% - 25\% atau lebih. Berdasarkan ketentuan tersebut, penelitian ini mengambil sampel sebanyak $10 \%$ dari populasi terjangkau, yaitu sebanyak 45 responden.

\subsubsection{Teknik Sampling}

Teknik pengambilan sampel dalam penelitian ini dilakukan dengan cara menggunakan teknik sampel stratified proporsional random sampling (area sampling), yaitu pengambilan sampel secara acak dari populasi yang berkelompok. Menurut Sugiyono (2012: 122) menyatakan bahwa "teknik sampling daerah ini sering digunakan melalui dua tahap, yaitu tahap pertama menentukan sampel daerah, tahap berikutnya menentukan orang-orang yang ada pada daerah itu secara sampling juga". Pada penelitian ini, tahap pertama menentukan 3 sekolah secara acak (random). Dari 3 sekolah dipilih seluruh kelas VIII yang terdapat di 3 SMP Swasta Kota Tangerang Selatan. Tahap selanjutnya diambil secara acak. Karena jumlah subjek cukup besar, maka diambil $10 \%$ 
dari populasi terjangkau yang ada, maka dalam penelitian ini dapat diambil sampel sebanyak 45 siswa sebagai sampel.

\subsection{Metode Pengumpulan Data}

\subsubsection{Variabel Penelitian}

Variabel-variabel dalam penelitian ini adalah :

a. Variabel $X_{1}$ (Variabel bebas 1), yaitu kebiasaan belajar siswa.

b. Variabel $X_{2}$ (Variabel bebas 2 ), yaitu kecerdasan emosi siswa.

c. Variabel $\mathrm{X}_{3}$ (Variabel bebas 3), yaitu perhatian orang tua.

d. Variabel Y (Variabel Terikat), yaitu penguasaan konsep Matematika.

\subsubsection{Sumber Data}

Data yang dikumpulkan dalam penelitian ini kebiasaan belajar siswa, kecerdasan emosi siswa, perhatian orang tua, dan Penguasaan Konsep Matematika.

a. Data variabel $X_{1}$ diperoleh dari siswa yang menjadi responden yang terpilih menjadi sampel.

b. Data variabel $X_{2}$ diperoleh dari siswa yang menjadi responden yang terpilih menjadi sampel.

c. Data variabel $X_{3}$ diperoleh dari siswa yang menjadi responden yang terpilih menjadi sampel.

d. Data variabel $Y$ diperoleh dari siswa yang menjadi responden yang terpilih menjadi sampel.

\subsection{Teknik Pengumpulan Data}

a. Data kebiasaan belajar siswa, kecerdasan emosi, perhatian orang tua siswa pengumpulan data dilakukan dengan memberikan kuesioner kepada siswa dengan bentuk skala Likert, dengan 5 jenjang. Setelah Peneliti memperoleh data diperoleh selanjutnya peneliti melakukan transformasi data dari data ordinal menjadi data interval dengan teknik MSI (Method of Successive Interval). (Bambang Suwarsono, 2007:30)

b. Data Penguasaan Konsep Matematika, diperoleh dari hasil belajar siswa. Dengan Kompetensi Dasar: 1. Pengertian Suku Satu, Suku Dua, dan Suku Tiga dalam variabel; 2. Operasi pada bentuk Aljabar; 3. Pemfaktoran; 4. Pecahan Dalam Bentuk Aljabar 


\section{HASIL DAN PEMBAHASAN}

\subsection{Uji Persyaratan Analisis Regresi}

Uji Asumsi Klasik

a. Uji Normalitas Data

Persyaratan regresi yang baik jika data penelitian mengikuti distribusi normal.

Tabel 3.5. Uji Normalitas Data

\begin{tabular}{|c|c|c|c|c|c|}
\hline \multicolumn{6}{|c|}{ One-Sample Kolmogorov-Smirnov Test } \\
\hline & & $\begin{array}{c}\text { Penguasaan } \\
\text { Konsep } \\
\text { Matematika }\end{array}$ & $\begin{array}{c}\text { Kebiasaan } \\
\text { Belajar }\end{array}$ & $\begin{array}{c}\text { Kecerdasan } \\
\text { Emosi }\end{array}$ & $\begin{array}{l}\text { Perhatian } \\
\text { Orang Tua }\end{array}$ \\
\hline \multicolumn{2}{|l|}{$\mathrm{N}$} & 45 & 45 & 45 & 45 \\
\hline \multirow{2}{*}{$\begin{array}{l}\text { Normal } \\
\text { Parameters }{ }^{a, b}\end{array}$} & Mean & 82.00 & 62.04 & 74.64 & 79.87 \\
\hline & Std. Deviation & 11.261 & 14.574 & 9.975 & 12.020 \\
\hline \multirow{3}{*}{$\begin{array}{l}\text { Most Extreme } \\
\text { Differences }\end{array}$} & Absolute & .158 & .109 & .190 & .127 \\
\hline & Positive & .078 & .109 & .102 & .086 \\
\hline & Negative & -.158 & -.084 & -.190 & -.127 \\
\hline \multicolumn{2}{|c|}{ Kolmogorov-Smirnov Z } & 1.057 & .728 & 1.275 & .853 \\
\hline \multicolumn{2}{|c|}{ Asymp. Sig. (2-tailed) } & .214 & .664 & .077 & .461 \\
\hline \multicolumn{6}{|c|}{ a. Test distribution is Normal. } \\
\hline \multicolumn{6}{|c|}{ b. Calculated from data. } \\
\hline
\end{tabular}

Dari tabel di atas menunjukkan bahwa uji hipotesis yang menyatakan distribusi data pada analisis regresi ini mengikuti distribusi normal. Hal ini ditunjukkan dengan semua nilai Asymp. Sig > 0,05. Hal ini berarti semua data berdistribusi normal.

\section{a. Uji Multikolinearitas}

Uji multikolinieritas bertujuan untuk menguji apakah model regresi ditemukan adanya korelasi yang sempurna antarvariabel bebas (independent). Model regresi yang baik seharusnya tidak terjadi korelasi yang sempurna diantara variabel bebas. Salah satu cara untuk untuk mendeteksi adanya multikolinieritas adalah dengan melihat tolerance atau varian inflation factor (VIF). Apabila tolerance $<0,1$ atau nilai VIF $>10$ maka terjadi multikolinearitas.

Tabel 3.6. Uji Multikolinearitas

\begin{tabular}{|l|l|l|l|}
\hline \multicolumn{3}{|c|}{ Coefficients $^{\mathbf{a}}$} \\
\hline \multirow{2}{*}{ Model } & \multicolumn{2}{|c|}{ Collinearity Statistics } \\
\cline { 2 - 4 } & Tolerance & VIF \\
\hline \multirow{2}{*}{1} & (Constant) & & \\
\cline { 2 - 4 } & Kebiasaan belajar & 0.978 & 1.023 \\
\hline
\end{tabular}




\begin{tabular}{|l|l|l|l|}
\hline Kecerdasan emosi & 0.922 & 1.085 \\
\cline { 2 - 4 } & Perhatian orang tua & 0.932 & 1.073 \\
\hline
\end{tabular}

Hasil uji multikoliniearitas pada tabel di atas diketahui bahwa hasil semua niali Tolerance $>0,1$ atau semua nilai varian inflation factor $(\mathrm{VIF})<10$. Sehingga dapat dinyatakan bahwa tidak ada multikolinearitas antara kebiasaan belajar, kecerdasan emosi, dan perhatian orang tua pada analisis regresi ganda ini.

\section{b. Uji Heteroskedastisitas}

Pengertian heteroskedastisitas adalah apabila kesalahan atau residual yang diamati tidak memiliki varian yang konstan. Kondisi heteroskedastisitas sering terjadi pada data cross section, atau data yang diambil dari beberapa responden pada suatu waktu tertentu.

Salah satu metode untuk mendeteksi adanya heteroskedastisitas adalah dengan membuat scatter-plot antara standardized Residual (ZRESID) dan Standardized Predicted Value (Y topi). Pada gambar dibawah ini menunjukkan tidak ada perubahan e sepanjang Y topi, maka dinyatakan tidak ada heteroskedastisitas pada galat (error/residual) tersebut.

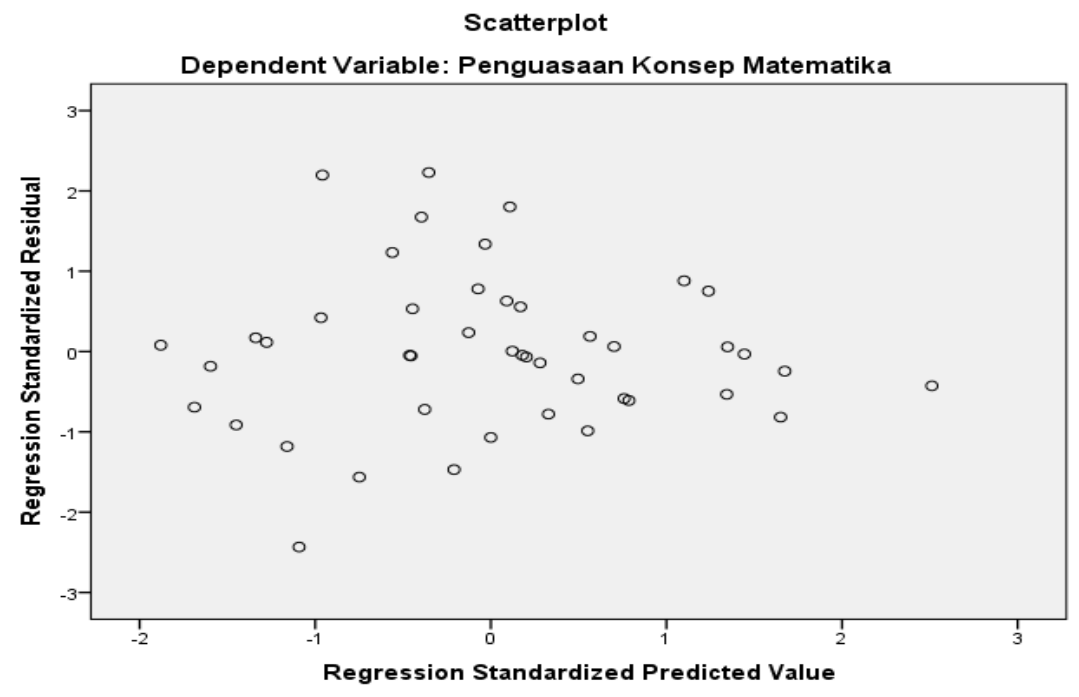

Gambar 3.3. Scatterplot Uji Heteroskedastisitas

Dari gambar di atas menunjukkan bahwa titik-titik menyebar secara acak dan tidak membentuk pola tertentu yang jelas, serta tersebar di atas maupun di bawah angka 0 pada sumbu Y. Hal ini menunjukkan bahwa tidak terjadi heteroskedastisitas pada model regresi 
tersebut, sehingga dapat dipakai untuk memprediksi variable penguasaan konsep Matematika berdasarkan kebiasaan belajar dan kecerdasan emosi.

b. Uji Normalitas Galat

Persyaratan regresi yang baik jika data penelitian mengikuti distribusi normal.

Tabel 3.7. Uji Normalitas Galat

\begin{tabular}{|c|c|c|}
\hline \multicolumn{3}{|c|}{ One-Sample Kolmogorov-Smirnov Test } \\
\hline & & $\begin{array}{c}\text { Unstandardize } \\
\text { d Residual }\end{array}$ \\
\hline \multicolumn{2}{|l|}{$\mathrm{N}$} & 45 \\
\hline \multirow{2}{*}{$\begin{array}{l}\text { Normal } \\
\text { Parameters }{ }^{a, b}\end{array}$} & Mean & 0E-7 \\
\hline & Std. Deviation & 8.12158912 \\
\hline \multirow{3}{*}{$\begin{array}{l}\text { Most Extreme } \\
\text { Differences }\end{array}$} & Absolute & .115 \\
\hline & Positive & .115 \\
\hline & Negative & -.049 \\
\hline \multicolumn{2}{|c|}{ Kolmogorov-Smirnov Z } & .768 \\
\hline \multicolumn{2}{|c|}{ Asymp. Sig. (2-tailed) } & .597 \\
\hline \multicolumn{3}{|c|}{ a. Test distribution is Normal. } \\
\hline
\end{tabular}

Dari tabel di atas menunjukkan bahwa uji hipotesis yang menyatakan distribusi residual pada analisis regresi ini mengikuti distribusi normal. Hal ini ditunjukkan dengan nilai $\mathrm{Z}=0,768$ dan Sig. $=0,597>0,05$. Hal ini berarti asumsi atau persyaratan analisis regresi terpenuhi.

\section{Uji Linearitas}

Uji linearitas dilakukan untuk menentukan teknik dalam analisis regresi apakah variabel bebas $\left(\mathrm{X}_{1}\right.$ dan $\left.\mathrm{X}_{2}\right)$ dan variabel terikat $(\mathrm{Y})$ terbentuk linear. Uji linearitas ini menggunakan perhitungan SPSS 20.0

a. Linearitas Regresi pengaruh variabel $\mathrm{X}_{1}$ atas $\mathrm{Y}$

Hasil uji linearitas regresi antara kebiasaan belajar dengan penguasaan konsep Matematika, perhitungan SPSS 20.0 sebagai berikut:

Tabel 3.8. Hasil Pengujian Linearitas Regresi Variabel $\mathrm{Y}$ atas $\mathrm{X}_{1}$

\begin{tabular}{|c|c|c|c|c|c|}
\hline \multicolumn{7}{|c|}{ ANOVA Table } \\
\hline & $\begin{array}{c}\text { Sum of } \\
\text { Squares }\end{array}$ & df & Mean & Square & Sig. \\
\hline
\end{tabular}




\begin{tabular}{|c|c|c|c|c|c|c|c|}
\hline \multirow{5}{*}{$\begin{array}{l}\text { Penguasaan } \\
\text { Konsep Matematika } \\
{ }^{*} \text { Kebiasaan Belajar }\end{array}$} & \multirow[b]{3}{*}{$\begin{array}{l}\text { Between } \\
\text { Groups }\end{array}$} & (Combined) & 4175.833 & 29 & 143.994 & 1.538 & .191 \\
\hline & & Linearity & 638.072 & 1 & 638.072 & 6.816 & .020 \\
\hline & & $\begin{array}{l}\text { Deviation } \\
\text { from } \\
\text { Linearity }\end{array}$ & 3537.761 & 28 & 126.349 & 1.350 & 275 \\
\hline & \multicolumn{2}{|c|}{ Within Groups } & 1404.167 & 15 & 93.611 & & \\
\hline & \multicolumn{2}{|l|}{ Total } & 5580.000 & 44 & & & \\
\hline
\end{tabular}

Berdasarkan hasil perhitungan di atas diperoleh hasil perhitungan Deviation from Linearity dengan $\mathrm{Fo}=1,350$ dan Sig. $=0,275>0,05$. Hal ini memiliki pengertian bahwa variabel kebiasaan belajar dengan penguasaan konsep Matematika siswa mempunyai mempunyai hubungan yang linear.

b. Linearitas Regresi pengaruh variable $\mathrm{X}_{2}$ atas $\mathrm{Y}$

Hasil uji linearitas regresi antara kecerdasan emosi dengan penguasaan konsep Matematika, perhitungan SPSS 20.0 sebagai berikut:

Tabel 3.9. Hasil Pengujian Linearitas Regresi Variabel $\mathrm{Y}$ atas $\mathrm{X}_{2}$

\begin{tabular}{|c|c|c|c|c|c|c|c|}
\hline \multicolumn{8}{|c|}{ ANOVA Table } \\
\hline & & & $\begin{array}{l}\text { Sum of } \\
\text { Squares }\end{array}$ & $\mathrm{df}$ & $\begin{array}{l}\text { Mean } \\
\text { Square }\end{array}$ & $F$ & Sig. \\
\hline \multirow{5}{*}{$\begin{array}{l}\text { Penguasaan } \\
\text { Konsep } \\
\text { Matematika* } \\
\text { Kecerdasan } \\
\text { Emosi }\end{array}$} & \multirow[b]{3}{*}{$\begin{array}{l}\text { Between } \\
\text { Groups }\end{array}$} & (Combined) & 2455.119 & 17 & 144.419 & 1.248 & .296 \\
\hline & & Linearity & 645.400 & 1 & 645.400 & 5.576 & .026 \\
\hline & & $\begin{array}{l}\text { Deviation } \\
\text { from } \\
\text { Linearity }\end{array}$ & 1809.719 & 16 & 113.107 & .977 & .505 \\
\hline & \multicolumn{2}{|c|}{ Within Groups } & 3124.881 & 27 & 115.736 & & \\
\hline & \multicolumn{2}{|l|}{ Total } & 5580.000 & 44 & & & \\
\hline
\end{tabular}

Berdasarkan hasil perhitungan di atas diperoleh hasil Deviation from Linearity dengan Fo $=0,977$ dan Sig. $=0,505>0,05$. Hal ini memili pengertian bahwa variabel kecerdasan emosi dengan penguasaan konsep Matematika siswa mempunyai mempunyai hubungan yang linear.

c. Linearitas Regresi pengaruh variabel $\mathrm{X}_{3}$ atas $\mathrm{Y}$

Hasil uji linearitas regresi antara perhatian orang tua dengan penguasaan konsep Matematika, perhitungan SPSS 20.0 sebagai berikut:

Tabel 3.10. Hasil Pengujian Linearitas Regresi Variabel $\mathrm{Y}$ atas $\mathrm{X}_{3}$

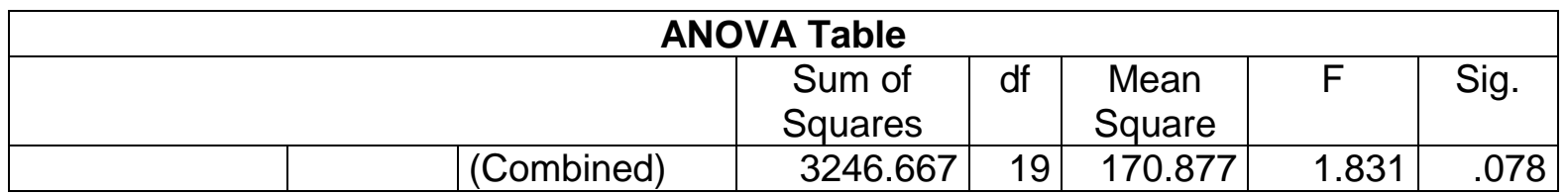




\begin{tabular}{|c|c|c|c|c|c|c|c|}
\hline \multirow{4}{*}{$\begin{array}{l}\text { Penguasaan } \\
\text { Konsep } \\
\text { Matematika* } \\
\text { Perhatian } \\
\text { Orang Tua }\end{array}$} & \multirow[b]{2}{*}{$\begin{array}{l}\text { Between } \\
\text { Groups }\end{array}$} & Linearity & 1457.550 & 1 & 1457.550 & 15.617 & .001 \\
\hline & & $\begin{array}{l}\text { Deviation from } \\
\text { Linearity }\end{array}$ & 1789.117 & 18 & 99.395 & 1.065 & .43 \\
\hline & \multicolumn{2}{|c|}{ Within Groups } & 2333.333 & 25 & 93.333 & & \\
\hline & \multicolumn{2}{|l|}{ Total } & 5580.000 & 44 & & & \\
\hline
\end{tabular}

Berdasarkan hasil perhitungan di atas diperoleh hasil Deviation from Linearity dengan Fo = 1,065 dan Sig. = 0,434 > 0,05. Hal ini memili pengertian bahwa variabel perhatian orang tua dengan penguasaan konsep Matematika siswa mempunyai mempunyai hubungan yang linear.

\subsection{Pengujian Hipotesis}

Pengajuan hipotesis dilakukan sesuai dengan ketentuan yang telah dijelaskan dalam Bab III. Hasil perhitungan dan pengujian bisa dilihat pada tabel di bawah ini:

Tabel 3.11. Hasil Perhitungan Pengujian Koefisien Korelasi Ganda Variabel $\mathrm{X}_{1}$ dan $\mathrm{X}_{2}$ terhadap Y

\begin{tabular}{|l|c|r|c|c|}
\hline \multicolumn{5}{|c|}{ Model Summary } \\
\hline Model & $\mathrm{R}$ & $\mathrm{R}$ Square & $\begin{array}{c}\text { Adjusted R } \\
\text { Square }\end{array}$ & $\begin{array}{c}\text { Std. Error of the } \\
\text { Estimate }\end{array}$ \\
\hline 1 & $.693^{\mathrm{a}}$ & .480 & .442 & 8.413 \\
\hline \multicolumn{3}{|c|}{$\begin{array}{l}\text { a. Predictors: (Constant), Perhatian Orang Tua, } \\
\text { Kebiasaan Belajar , Kecerdasan Emosi }\end{array}$} \\
\hline
\end{tabular}

Tabel 3.12. Hasil Perhitungan Pengujian Signifikansi Koefisien Regresi Variabel $\mathrm{X}_{1}$, $\mathrm{X}_{2}$ dan $\mathrm{X}_{3}$ terhadap $\mathrm{Y}$

\begin{tabular}{|c|c|c|c|c|c|}
\hline \multicolumn{6}{|c|}{ ANOVA $^{a}$} \\
\hline Model & $\begin{array}{l}\text { Sum of } \\
\text { Squares }\end{array}$ & df & $\begin{array}{l}\text { Mean } \\
\text { Square }\end{array}$ & $\mathrm{F}$ & Sig. \\
\hline Regression & 2677.751 & 3 & 892.584 & 12.610 & $.000^{\mathrm{b}}$ \\
\hline Residual & 2902.249 & 41 & 70.787 & & \\
\hline Total & 5580.000 & 44 & & & \\
\hline \multicolumn{6}{|c|}{ a. Dependent Variable: Penguasaan Konsep Matematika } \\
\hline \multicolumn{6}{|c|}{$\begin{array}{l}\text { b. Predictors: (Constant), Perhatian Orang Tua, Kebiasaan } \\
\text { Belajar, Kecerdasan Emosi }\end{array}$} \\
\hline
\end{tabular}

Tabel 3.13. Hasil Perhitungan Persamaan Regresi Ganda Variabel $X_{1}, X_{2}$ dan $X_{3}$ terhadap Y

\section{Coefficients $^{\mathrm{a}}$}




\begin{tabular}{|c|c|c|c|c|c|c|}
\hline \multirow{2}{*}{\multicolumn{2}{|c|}{ Model }} & \multicolumn{2}{|c|}{$\begin{array}{l}\text { Unstandardized } \\
\text { Coefficients }\end{array}$} & $\begin{array}{c}\text { Standardized } \\
\text { Coefficients }\end{array}$ & \multirow[t]{2}{*}{ t } & \multirow[t]{2}{*}{ Sig. } \\
\hline & & $B$ & Std. Error & Beta & & \\
\hline \multirow{4}{*}{1} & (Constant) & 49.376 & 15.504 & & 3.185 & .003 \\
\hline & Kebiasaan Belajar & .324 & .088 & .419 & 3.678 & .001 \\
\hline & $\begin{array}{l}\text { Kecerdasan } \\
\text { Emosi }\end{array}$ & .311 & .132 & 276 & 2.351 & .024 \\
\hline & Perhatian Orang Tua & .448 & .109 & .478 & 4.099 & .000 \\
\hline
\end{tabular}

a. Dependent Variable: Penguasaan Konsep Matematika

1. Pengaruh kebiasaan belajar $\left(X_{1}\right)$, kecerdasan emosi $\left(X_{2}\right)$ dan perhatian orang tua $\left(X_{3}\right)$ secara bersama-sama terhadap penguasaan konsep Matematika (Y)

Hipotesis yang diuji:

$H_{0}: \beta_{y 1}=\beta_{y 2}=\beta_{y 3}=0$

$H_{1}: \beta_{y 1} \neq 0, \beta_{y 2} \neq 0, \beta_{y 3} \neq 0$

Artinya:

$\mathrm{H}_{0}$ : tidak terdapat pengaruh kebiasaan belajar dan kecerdasan emosi secara bersamasama terhadap penguasaan konsep Matematika

$\mathrm{H}_{1}$ : terdapat pengaruh kebiasaan belajar dan kecerdasan emosi secara bersama-sama terhadap penguasaan konsep Matematika.

Dari table 3.12 dapat dinyatakan bahwa terdapat pengaruh yang signifikan kebiasaan belajar, kecerdasan emosi, dan perhatian orang tua secara bersama-sama terhadap penguasaan konsep Matematika. Hal ini dibuktikan dengan perolehan nilai Fo = 12,610 dan Sig. $0,000<0,05$

Sementara itu, persamaan garis regresi ganda dapat dinyatakan dengan $\hat{Y}=49,376$ $+0,324 X_{1}+0,311 X_{2}+0,448 X_{3}$. Hal ini memiliki pengertian bahwa variable kebiasaan belajar, kecerdasan emosi, dan perhatian orang tua memberikan kontribusi positif terhadap variabel penguasaan konsep Matematika. Dari tabel 3.11 juga dapat menjelaskan bahwa secara bersama-sama variable kebiasaan belajar, kecerdasan emosi, dan perhatian orang tua memberikan kontribusi sebesar $48 \%$ terhadap variable penguasaan konsep Matematika.

2. Pengaruh Kebiasaan belajar terhadap Penguasaan konsep Matematika Hipotesis yang diuji:

$$
\begin{aligned}
& H_{0}: \beta_{y 1}=0 \\
& H_{1}: \beta_{y 1} \neq 0
\end{aligned}
$$


Artinya:

$\mathrm{H}_{0}$ : tidak terdapat pengaruh kebiasaan belajar terhadap penguasaan konsep Matematika

$\mathrm{H}_{1}$ : terdapat pengaruh kebiasaan belajar terhadap penguasaan konsep Matematika

Dari tabel 3.13 dapat dinyatakan bahwa terdapat pengaruh yang signifikan kebiasaan belajar terhadap penguasaan konsep Matematika. Hal ini dibuktikan dengan perolehan nilai thitung $=3,678$ dan Sig. $0,001<0,05$.

Adapun kontribusi variabel kebiasaan belajar terhadap penguasaan konsep Matematika dapat dinyatakan dengan rumus:

$\mathrm{KD}=$ Nilai $\beta_{x 1 y} \times$ Nilai Korelasi Pasialnya $\left(r_{x 1 y}\right) \times 100 \%$

$\mathrm{KD}=0,419 \times 0,338 \times 100 \%=14,16 \%$

Dari hasil perhitungan di atas dapat dinyatakan bahwa kontribusi kebiasaan belajar dalam meningkatkan penguasaan konsep Matematika sebesar 14,16\%

3. Pengaruh Kecerdasan emosi terhadap Penguasaan konsep Matematika Hipotesis yang diuji:

$$
\begin{aligned}
& H_{0}: \beta_{y 2}=0 \\
& H_{1}: \beta_{y 2} \neq 0
\end{aligned}
$$

Artinya:

$\mathrm{H}_{0}$ : tidak terdapat pengaruh kecerdasan emosi terhadap penguasaan konsep Matematika

$\mathrm{H}_{1}$ : terdapat pengaruh kecerdasan emosi terhadap penguasaan konsep Matematika

Dari tabel 4.13 dapat dinyatakan bahwa terdapat pengaruh yang signifikan kecerdasan emosi terhadap penguasaan konsep Matematika. Hal ini dibuktikan dengan perolehan nilai $t_{\text {hitung }}=2,351$ dan Sig. $0,024<0,05$.

Adapun kontribusi variabel kecerdasan emosi terhadap penguasaan konsep Matematika dapat dinyatakan dengan rumus:

$\mathrm{KD}=$ Nilai $\beta_{x 2 y}$ x Nilai Korelasi Pasialnya $\left(r_{x 2 y}\right) \times 100 \%$

$\mathrm{KD}=0,276 \times 0,340 \times 100 \%=9,38 \%$

Dari hasil perhitungan di atas dapat dinyatakan bahwa kontribusi kecerdasan emosi dalam meningkatkan penguasaan konsep Matematika sebesar 3,38 \%.

4. Pengaruh perhatian orang tua $\left(\mathrm{X}_{3}\right)$ terhadap penguasaan konsep Matematika (Y)

Hipotesis yang diuji: 


$$
\begin{aligned}
& H_{0}: \beta_{y 3}=0 \\
& H_{1}: \beta_{y 3} \neq 0
\end{aligned}
$$

Artinya:

$\mathrm{H}_{0}$ : tidak terdapat pengaruh dan perhatian orang tua terhadap penguasaan konsep Matematika

$\mathrm{H}_{1}$ : terdapat pengaruh dan perhatian orang tua terhadap penguasaan konsep Matematika

Dari table 4.13 dapat dinyatakan bahwa terdapat pengaruh yang signifikan perhatian orang tua terhadap penguasaan konsep Matematika. Hal ini dibuktikan dengan perolehan nilai $t_{\text {hitung }}=4,099$ dan Sig. $0,000<0,05$.

Adapun kontribusi variabel dan perhatian orang tua terhadap penguasaan konsep Matematika dapat dinyatakan dengan rumus:

$\mathrm{KD}=$ Nilai $\beta_{x 3 y}$ x Nilai Korelasi Pasialnya $\left(r_{x 3 y}\right) \times 100 \%$ $\mathrm{KD}=0,478 \times 0,511 \times 100 \%=24,43 \%$

Dari hasil perhitungan di atas dapat dinyatakan bahwa kontribusi dan perhatian orang tua dalam meningkatkan penguasaan konsep Matematika sebesar 24,43\%.

\subsection{Pembahasan}

1. Pengaruh Kebiasaan belajar (X1), Kecerdasan emosi (X2), dan Perhatian orang tua (X3) secara bersama-sama terhadap Penguasaan konsep Matematika (Y)

Hasil penelitian di atas menyimpulkan bahwa persepsi atas tingkat pendidikan orang tua, kecerdasan emosi dan perhatian orang tua secara bersama-sama telah memberikan pengaruh positif terhadap peningkatan penguasaan konsep Matematika siswa di SMP Swasta di Kota Tangerang Selatan. Hal ini mengandung arti bahwa kebiasaan belajar, kecerdasan emosi, dan dan perhatian orang tua telah memberikan pengaruh yang signifikan terhadap peningkatan prestasi belajar siswa SMP Swasta di Kota Tangerang Selatan.

Matematika pada hakekatnya merupakan sistem aksiomatis deduktif formal. Sebagai suatu sistem aksiomatis, matematika memuat komponen-komponen dan aturan komposisi atau pengerjaan yang dapat menjalin hubungan secara fungsional antar komponen. Sehingga, matematika dikenal sebagai pengetahuan yang terstruktur, sistematis, tersusun secara hierarkis, dan terjalin hubungan fungsional yang erat antar 
komponen. Komponen-komponen tersebut adalah fakta, konsep, prinsip dan prosedur. Ini berarti fakta, konsep, prinsip dan prosedur tersebut tersusun secara hierarkis.

Menurut Sumarmo (2013:4) menyatakan bahwa secara garis besar kemampuan dasar matematika dapat diklasifikasikan dalam lima standar, yaitu (1) mengenal, memahami, dan menerapkan konsep, prosedur, prinsip dan idea matematika, (2) menyelesaikan masalah matematika (mathematical problem solving), (3) bernalar matematika (mathematical reasoning), (4) melakukan koneksi matematika (mathematical connection), dan (5) komunikasi matematika (mathematical communication).

Matematika secara umum sangat sulit dipahami oleh siswa, karena matematika memiliki obyek yang sifatnya abstrak dan membutuhkan penalaran yang cukup tinggi untuk memahami setiap konsep-konsep matematika yang sifatnya hirarkis, sehingga perlu menerapkan model-model pengajaran yang lebih baik dan tepat membantu penguasaan siswa sedini mungkin di tingkat sekolah terhadap matematika. Tetapi perlu kita garis bawahi pula sebuah pengajaran yang baik tidak cukup untuk mendapatkan hasil belajar siswa yang optimal, karena yang menjadi salah satu masalah yang dihadapi guru untuk menyelenggarakan pengajaran matematika adalah bagaimana menumbuhkan dan merangsang kemampuan penalaran (logika) serta penguasaan konsep dengan benar oleh siswa.

Penguasaan konsep Matematika membantu siswa untuk mengingat, hal tersebut dikarenakan idea-idea Matematika yang dipelajari melalui penguasaan adalah saling terhubung. Mereka dapat lebih mudah untuk mengingat dan menggunakan, serta dapat menyusun kembali pada saat mereka lupa, siswa yang mengingat kembali apa yang mereka pahami dan mencoba untuk mempresentasikan kedalam sendiri.

Pada dasarnya hasil kemampuan penguasaan konsep matematika dipengaruhi oleh beberapa faktor diantaranya faktor intelegensia atau kecerdasaan. Faktor intelegensi atau kecerdasan merupakan salah satu faktor terpenting pada peserta didik. Karena dengan tingkat kecerdasan yang tinggi seorang siswa dapat menyelesaikan soalsoal secara cepat dan tepat. Tetapi kecerdasan bukan satu satunya tolak ukur seorang siswa memperoleh prestasi yang tinggi, karena bisa saja seorang siswa dengan tingkat kecerdasannya biasa saja dapat mempunyai prestasi yang tinggi dibandingkan dengan 
siswa yang mempunyai tingkat kecerdasan yang tinggi. Itu semua bisa terjadi karena faktor-faktor lain yang mempengaruhinya.

\section{Pengaruh Kebiasaan belajar terhadap Penguasaan konsep Matematika}

Hasil penelitian di atas menyimpulkan bahwa kebiasaan belajar telah memberikan pengaruh positif terhadap peningkatan penguasaan konsep Matematika siswa di SMP Swasta di Kota Tangerang Selatan. Hal ini mengandung arti bahwa kebiasaan belajar siswa memberikan pengaruh yang cukup signifikan terhadap peningkatan penguasaan konsep Matematika siswa di SMP Swasta di Kota Tangerang Selatan.

Kebiasaan belajar siswa merupakan salah satu faktor pendukung keberhasilan siswa dalam menempuh jenjang belajar yang sedang ditempuh siswa tersebut. Bila kebiasaan belajar baik, maka prestasi yang diharapkan tentunya juga baik. Kebiasan ini dapat timbul dari sikap mental yang tepat terhadap hal-hal yang berhubungan dengan aktifitas belajar. Disiplin pribadi diperlukan pula untuk mengembangkan kebiasaankebiasaan baik itu sehingga kelak dapat terlaksana tanpa banyak kesulitan.

Kebiasaan belajar merupakan persoalan setiap siswa. Mereka memiliki kebiasaan belajar yang khas yang disesuaikan dengan selera dan kondisi masing- masing individu. Berbagai kebiasaan dapat berupa cara mereka dalam mempelajari materi suatu pelajaran, kebiasaan istirahat sejenak pada saat belajar, keteraturan dalam belajar, mendengarkan musik saat belajar, dan sebagainya. Kebiasaan mempelajari suatu materi pelajaran antara siswa yang satu dengan yang lain berbeda-beda dalam arti ada siswa yang biasa mempelajari materi pelajaran dengan cara hafalan, adapula siswa yang lainnya yang lebih menyukai dengan memusatkan perhatiannya pada pengertian atau pemecahan suatu masalah. Dilihat dari segi bentuk belajarnya, siswa yang satu lebih suka dengan belajar berkelompok dengan temannya, namun siswa yang lain justru tidak menyukainya dengan alasan tidak bisa konsentrasi. Kenyataan tersebut semuanya bermula dari kondisi fisik dan psikis yang berbeda, latar belakang ekonomi yang tidak sama, ingatan, pikiran, daya kemampuan menyerap materi pelajaran, minat, perbedaan kebiasaan para siswa yang berbeda antara satu dengan yang lainnya.

Pada umumnya kebiasaan belajar yang dilakukan para siswa baik di rumah maupun di sekolah, bahwa adanya kecenderungan melakukan tingkah laku belajar apabila 
mereka akan menghadapi ulangan atau ujian dan ada pekerjaan rumah saja. Siswa yang mempunyai kebiasaan belajar yang baik maka akan memperoleh prestasi belajar yang baik pula, sebaliknya siswa yang kebiasaan belajarnya tidak baik, maka prestasi belajarnya tidak akan maksimal. Cara belajar yang dipergunakan turut menentukan hasil belajar yang diharapkan. Cara yang tepat akan membawa hasil yang memuaskan, sedangkan cara yang tidak sesuai akan menyebabkan belajar itu kurang berhasil”.

\section{Pengaruh Kecerdasan emosi terhadap Penguasaan konsep Matematika}

Dari hasil penelitian dan teori yang ada dapat disimpulkan bahwa kecerdasan emosi telah memberikan pengaruh positif terhadap peningkatan penguasaan konsep Matematika siswa di SMP Swasta di Kota Tangerang Selatan. Artinya, kebiasaan belajar yang tinggi telah memberikan pengaruh positif terhadap peningkatan penguasaan konsep Matematika siswa SMP Swasta di Kota Tangerang Selatan.

Seiring dengan perkembangan ilmu pengetahuan dan teknologi, kini kecerdasan emosi manusia sangat berperan dalam segala aspek kehidupan manusia. Kecerdasan emosi adalah kemampuan mengenali perasaan kita sendiri dan perasaan peserta didik lain, kemampuan memotivasi diri sendiri, dan kemampuan mengelola emosi dengan baik pada diri sendiri dan dalam hubungan dengan peserta didik lain. Peserta didik yang mempunyai kecerdasan emosi yang tinggi merupakan peserta didik yang dapat meraih kesuksesan pekerjaan, hubungan jangka panjang dengan peserta didik lain serta memiliki kerja yang seimbang dan kehidupan rumah tangga.

Kecerdasan emosi merupakan kemampuan untuk menggunakan emosi secara efektif dalam mengelola diri sendiri dan mempengaruhi hubungan dengan orang lain secara positif. Menurut Salovey dan Mayer, (handbook Emotional Intelligence training, prime consulting, 2004:11) kecerdasan emosi adalah kemampuan untuk merasakan emosi, menerima dan membangun emosi dengan baik, memahami emosi dan pengetahuan emosional sehingga dapat meningkatkan perkembangan emosi dan intelektual.

Salovey juga memberikan definisi dasar tentang kecerdasan emosi dalam lima wilayah utama yaitu, kemampuan mengenali emosi diri, mengelola emosi diri, memotivasi diri sendiri, mengenali emosi orang kain, dan kemampuan membina hubungan dengan orang lain. Seorang ahli kecerdasan emosi, Goleman (2000:xiii) 
mengatakan bahwa yang dimaksud dengan kecerdasan emosi di dalamnya termasuk kemampuan mengontrol diri, memacu, tetap tekun, serta dapat memotivasi diri sendiri. Kecakapan tersebut mencakup pengelolaan bentuk emosi baik yang positif maupun negatif. Kecerdasan emosi adalah kemampuan di bidang emosi yaitu kesanggupan menghadapi frustasi, kemampuan mengendalikan emosi, semamgat optimisme, dan kemampuan menjalin hubungan dengan orang lain atau empati. penggunaan emosi yang efektif akan dapat mencapai tujuan dalam pembelajaran.

\section{Pengaruh Perhatian orang tua (X3) terhadap Penguasaan konsep Matematika (Y)}

Dari hasil penelitian dan teori yang ada dapat disimpulkan bahwa perhatian orang tua telah memberikan pengaruh positif terhadap peningkatan penguasaan konsep Matematika siswa di SMP Swasta di Kota Tangerang Selatan. Artinya, adanya perhatian orang tua yang tinggi telah memberikan pengaruh positif terhadap peningkatan penguasaan konsep Matematika siswa SMP Swasta di Kota Tangerang Selatan.

Perhatian orang tua sangat diperlukan untuk menanamkan disiplin belajar pada anak-anaknya, misalnya mengatur waktu bermain, mengatur dalam menonton televisi, membaca buku, majalah, dan koran perlu adanya pengawasan atau perhatian dari orang tua, meskipun kita juga perlu memberi kebebasan bagi anak. Kebebasan yang dimaksud adalah kebebasan yang tetap terkendali atau terpantau oleh orang tua. Banyak kita jumpai sebagai orang tua tidak peduli dengan hal-hal yang demikian, mereka masa bodoh dengan apa yang dilakukan oleh anaknya. Mereka selalu beralasan yang lelah seharian, kerja yang sibuk, dan menyibukkan diri dengan berbagai acara dan berbagai alasan yang mengakibatkan tidak sempat memperhatikan belajar anaknya.

Perhatian orangtua sangat diperlukan untuk menanamkan disiplin belajar pada anak-anaknya, misalnya mengatur waktu bermain, mengatur dalam menonton televisi, membaca buku, majalah, dan koran perlu adanya pengawasan atau perhatian dari orang tua, meskipun kita juga perlu memberi kebebasan bagi anak. Kebebasan yang dimaksud adalah kebebasan yang tetap terkendali atau terpantau oleh orang tua. Banyak kita jumpai sebagai orang tua tidak peduli dengan hal-hal yang demikian, mereka masa bodoh dengan apa yang dilakukan oleh anaknya. Mereka selalu beralasan yang lelah seharian, kerja yang sibuk, dan menyibukkan diri dengan berbagai acara dan berbagai alasan yang mengakibatkan tidak sempat memperhatikan belajar anaknya. Berdasarkan kasus-kasus 
di atas, jika seorang anak ingin sukses dalam belajarnya maka harus dipahami bentukbentuk perhatian orang tua yang dapat dilakukan pada anaknya.

Bentuk perhatian orang tua terhadap belajar anak dapat berupa pemberian bimbingan dan nasihat, pengawasan terhadap belajar anak, pemberian motivasi dan penghargaan serta pemenuhan kebutuhan belajar anak.

Menurut Oemar Hamalik dengan mengutip pendapat Stikes dan Dorcy, menyatakan bahwa bimbingan adalah "suatu proses untuk menolong individu dan kelompok supaya individu itu dapat menyesuaikan diri dan memecahkan masalah-masalahnya" (Oemar Hamalik 2002:93). Kemudian ia juga mengutip pendapat Stoops, yang menyatakan bimbingan adalah "suatu proses yang terus menerus untuk membantu perkembangan individu dalam rangka mengembangkan kemampuannya secara maksimal untuk memperoleh manfaat yang sebesar-besarnya, baik bagi dirinya maupun bagi masyarakat.”

\section{SIMPULAN DAN SARAN}

Pada bagian kesimpulan ini, penulis uraikan secara singkat hasil penelitian yang diperoleh di lapangan dapat ditarik simpulan sebagai berikut :

1. Terdapat pengaruh yang signifikan kebiasaan belajar, kecerdasan emosi, dan perhatian orang tua secara bersama-sama terhadap penguasaan konsep Matematika. Hal ini dibuktikan dengan perolehan nilai Fo $=12,610$ dan Sig. 0,000 < 0,05. Secara bersamasama variable kebiasaan belajar, kecerdasan emosi, dan perhatian orang tua memberikan kontribusi sebesar $48 \%$ terhadap variable penguasaan konsep Matematika.

2. Terdapat pengaruh yang signifikan kebiasaan belajar terhadap penguasaan konsep Matematika. Hal ini dibuktikan dengan perolehan nilai $t_{\text {hitung }}=3,678$ dan Sig. 0,001 < 0,05 . Variabel kebiasaan belajar memberikan kontribusi sebesar $14,16 \%$ dalam meningkatkan penguasaan konsep Matematika penguasaan konsep Matematika.

3. Terdapat pengaruh yang signifikan kecerdasan emosi terhadap penguasaan konsep Matematika. Hal ini dibuktikan dengan perolehan nilai $t_{\text {hitung }}=2,351$ dan Sig. 0,024< 0,05. Variabel kecerdasan emosi memberikan kontribusi sebesar 9,38 \% dalam meningkatkan penguasaan konsep Matematika.

4. Terdapat pengaruh perhatian orang tua terhadap penguasaan konsep Matematika. Hal ini dibuktikan dengan perolehan nilai $t_{\text {hitung }}=4,099$ dan Sig. $0,000<0,05$. Variabel 
perhatian orang tua memberikan kontribusi sebesar $24,43 \%$ dalam meningkatkan penguasaan konsep Matematika penguasaan konsep Matematika.

\section{DAFTAR PUSTAKA}

A. Muri Yusuf. 2014. Metode Penelitian. Jakarta: Prenadamedia Group.

Abdul Rahman Saleh. 2008. Psikologi Suatu Pengantar dalam Perspektif Islam. Jakarta: Kencana.

Boyatzis, R.E. Ron, S. 2001. Unleashing the Power of Self Directed Learning. Case Western Reserve University, Cleveland, Ohio, USA.

Depdiknas 2006. Undang-Undang Republik Indonesia No. 20 tahun 2003 tentang Sistem Pendidikan Nasional. Jakarta: Departemen Pendidikan Nasional.

Depdiknas. 2004. Peraturan Dirjen Dikdasmen Depdiknas No. 506/C/PP/2004 indikator yang menunjukkan penguasaan atau pemahaman konsep. Jakarta: Departemen Pendidikan Nasional.

Dimyati dan Mudjiono. 2006. Belajar dan Pembelajaran. Jakarta: PT Rineka Cipta

Goleman. D. 2000. Kecerdasan Emosi: Mengapa Emotional Intelligence lebih tinggi dari pada IQ. Alih bahasa: T. Hermay. PT. Gramedia Pustaka Utama. Jakarta.

Jonathan Sarwono. 2012. Mengenal SPSS Statistic 20. Jakarta: PT Elex Media Komputindo.

Sudjana. 2009. Metoda Statistika. Bandung: Tarsito.

Sugiyono. 2008. Metode Penelitian Kuantitatif, Kualitatif, dan R\&D, Bandung: Alfabeta

Sugiyono. 2010. Statistika untuk Penelitian. Bandung: Alfabeta 